\title{
Apis mellifera discrimination between flowers of commercial types of melon and implications to crop pollination ${ }^{1}$
}

\author{
Discriminação de Apis mellifera entre flores de tipos comerciais de melão e \\ implicações na polinização da cultura
}

\author{
Nayanny de Sousa Fernandes ${ }^{2}$, Gercy Soares Pinto² ${ }^{2}$ Guilherme Julião Zocolo ${ }^{3}$, Fernando Antonio Souza de \\ Aragão $^{4 *}$ and Breno Magalhães Freitas ${ }^{5}$
}

\begin{abstract}
We investigated the foraging pattern of A. mellifera in five commercial types of melon (Yellow, Cantaloupe, Charentais, Galia and Piel de Sapo) grown side by side. We also observed if this bee species can discriminate between flowers of the five melon types and if it shows preference for flowers of any of them. Results showed that the bees visit flowers of all types of melon throughout the day collecting pollen and nectar in similar foraging patterns. However, they visited significantly more flowers of the Cantaloupe type followed by the types Piel de Sapo and Yellow, while the melons type Galia and Charentais were the least visited by the bees. This behavior has implications for the use of A. mellifera for melon pollination, requiring that the bees be managed according to the type of melon cultivated. It also highlights the need to find out what makes flowers of some melon types to be more visited than others in order to select within the less visited types of melon for cultivars more attractive to the bees.
\end{abstract}

Key words: Cantaloupe. Bee visits. Foraging behavior. Flower preference. Melon pollination.

\begin{abstract}
RESUMO - Investigamos o padrão de forrageamento de A. mellifera em cinco tipos comerciais de melão (Amarelo, Cantaloupe, Charentais, Gália e Pele de Sapo) cultivados lado a lado. Observamos também se esta espécie de abelha pode discriminar entre flores dos cinco tipos de melão e se mostra preferência por flores de qualquer um deles. Os resultados mostraram que as abelhas visitam flores de todos os tipos de melão ao longo do dia coletando pólen e néctar em padrões similares de forrageamento. No entanto, elas visitaram significativamente mais flores do tipo Cantaloupe, seguido dos tipos Pele de Sapo e Amarelo, enquanto os melões tipo Gália e Charentais foram os menos visitados pelas abelhas. Este comportamento tem implicações para o uso de A. mellifera na polinização do melão, exigindo que as abelhas sejam manejadas de acordo com o tipo de melão cultivado. Ele também destaca a necessidade de descobrir o que faz com que as flores de alguns tipos de melão sejam mais visitadas do que de outros, a fim de selecionar, dentro dos tipos de melão menos visitados, cultivares mais atraentes para as abelhas.
\end{abstract}

Palavras-chave: Cucumis melo. Visitas das abelhas. Comportamento de forrageamento. Preferência por flores. Polinização de melão.

\footnotetext{
DOI: $10.5935 / 1806-6690.20200027$

*Author for correspondence

Received for publication 06/08/2019; approved on 27/01/2020

${ }^{1}$ Parte da Tese de Doutorado em Zootecnia do primeiro autor, apresentada na Universidade Federal de Ceará/UFC

${ }^{2}$ Departamento de Zootecnia, Universidade Federal do Ceará/UFC, Fortaleza-CE, Brasil, nayanny@ msn.com (ORCID ID 0000-0001-6481-0916), gercy_pinto@zootecnista.com.br(ORCID ID 0000-0002-3074-9843)

${ }^{3}$ Embrapa Agroindústria Tropical, Fortaleza-CE, Brazil, guilherme.zocolo@embrapa.br (ORCID ID 0000-0001-8835-0184)

${ }^{4}$ Embrapa Agroindústria Tropical, Fortaleza-CE, Brazil, fernando.aragao@embrapa.br (ORCID ID 0000-0002-4041-7375)

${ }_{5}^{5}$ Departamento de Zootecnia, Universidade Federal do Ceará/UFC, Fortaleza-CE, Brasil, freitas@ufc.br (ORCID ID 0000-0002-9932-2207)
} 


\section{INTRODUCTION}

Melon (Cucumis melo L.) is a crop of great importance in the global scenario, being the third most cultivated curcubit in the world (FOOD AND AGRICULTURE ORGANIZATION OF THE UNITED NATIONS, 2018). However, it is a species essentially dependent on biotic pollination for fruit production, making it necessary for pollinating agents to transfer pollen grains from anthers to stigmas. The absence of pollinators in the melon can lead to productivity losses, implying production drops of $90 \%$ or more (KLEIN et al., 2007).

A number of bee species have been reported visiting melon flowers in various parts of the world (FREE, 1993; GÓMEZ et al., 2016; KIILL et al., 2014; KOUONON et al., 2009; TSCHOEKE et al., 2015). However, pollination in the vast majority of commercial melon crops is carried out by Apis mellifera L. (HOZ, 2007; KOUONON et al., 2009; REYES-CARRILLO; CANO-RÍOS; NAVA-CAMBEROS, 2009; RIBEIRO et al., 2015; SINGH; YADAV; CHHUNEJA, 2014; SOUSA et al., 2009), because it is an efficient pollinator, cosmopolitan and has well-established management techniques (DELAPLANE; MAYER, 2000). Therefore, to ensure high fruit yield, honeybee colonies are introduced to melon crops (FREE, 1993).

Honeybees visit flowers to obtain pollen and nectar which are essential for the feeding of young and adult bees (ABOU-SHAARA, 2014; FREE, 1993). The melon plant provides both resources in male and hermaphrodite flowers, or just nectar in female flowers, depending on the melon type. All genders of melon flowers are visited by A. mellifera (MUSSEN; THORP, 2003). However, floral gender, resources availability, time of the day and environmental conditions, among other biotic and abiotic factors can affect the time and pattern of bee visitation to the melon flowers (DELAPLANE; MAYER, 2000; FREE, 1993; HOZ, 2007).

A factor usually disregarded in the management of bees for pollination, is that most cultivated plant species have several varieties, types and cultivars, differing from each other enough to affect the attraction or efficiency of pollinators (FREE, 1993). In the case of melon, the species has numerous botanical varieties, but only three (inodorus, reticulatus and cantalupensis) are of commercial interest (PITRAT, 2008). In order to facilitate marketing, the cultivated melon of these varieties were grouped into a so-called "type" classification, among which the most traded are Yellow, Piel de Sapo and Honey Dew (inodorus), Cantaloupe and Galia (reticulatus) and Charentais (cantalupensis) (PITRAT; HANELT; HAMMER, 2000). Although A. mellifera bees visit flowers of the various melon types and apparently their flowers are similar and melon types are fully cross-fertile with one another (PITRAT 2016), greater difficulties in directing them to the pollination of some types of melon suggest that these bees can distinguish between flowers of the different melon types and may present preferences for flowers of some types in relation to flowers of others (BOMFIM et al., 2018; KIILL et al., 2016).

In the present study, we tested the hypotheses that A. mellifera bees used in melon pollination present (i) a similar foraging pattern (i.e. diel pattern of foraging) in the various commercial types of melon; (ii) ability to discriminate between flowers of different commercial types of melon and preference to visit flowers of some types in relation to others.

\section{MATERIAL AND METHODS}

\section{Experimental area and procedures}

The experiment was carried out in the dry season of 2015 (November) at the Experimental Field of the Brazilian Agricultural Research Corporation - Embrapa located in the municipality of Pacajus, state of Ceará, in NE Brazil, using an entirely randomized experimental design with five treatments (five commercial types of melon) and eight replications. The cultivation area $\left(800 \mathrm{~m}^{2}\right)$ consisted of 20 planting lines, each of them divided in half, totaling 40 plots. The seedlings were planted simultaneously at a spacing of $2.0 \mathrm{~m}$ between rows and $0.40 \mathrm{~m}$ between plants, so that each plot was composed of 25 plants.

Each type of melon was represented by a hybrid of good commercial acceptance, Yellow (Goldex), Cantaloupe (Zelda), Charentais (Banzai), Galia (McLaren) and Piel de Sapo (Ricura). The plants were drip irrigated, with foundation fertilization and cover fertilization made by fertirrigation. The plants were not sprayed any pesticide during all their lives in order to avoid interferences with bee visitation to the flowers of the different melon types.

Two strong colonies of the Africanized honey bee, Apis mellifera (40,000 individuals), reared in standard Langstroth hives were introduced in the area in order to ensure bee visitation to flowers of the different types of melon. The bees covered seven brood frames in the hive and were in good sanitary conditions. They were placed in a shade by the melon growing area and a source of clean water was made available. The colonies were provided by the Bee Unit of the Animal Science Department of the Federal University of Ceará - UFC.

Observations of the bee frequency to flowers were carried out directly and simultaneously in the different 
types of melon at the peak of plant flowering during four consecutive days and throughout the day, from 5 a.m. to 5 p.m. Three researchers observed and counted the number of bee visits to six male flowers and six hermaphrodite flowers of the five types of melon ( $\mathrm{n}=30$ for each flower gender) during the first 30 minutes of each hour. During the visit it was also recorded which floral resource, nectar or pollen, was collected by the bees. Information acquired was recorded in data sheets for later statistical analysis.

During the observation period of bees' visits to flowers of different types of melon, the temperature was lower in the morning (before 12 p.m.), with values as low as $22.6{ }^{\circ} \mathrm{C}$ early in the morning and average of $29.1{ }^{\circ} \mathrm{C}$, than in the afternoon (after 12 p.m.) when the air temperature was higher reaching peak of $35.2{ }^{\circ} \mathrm{C}$, and average of $32.7{ }^{\circ} \mathrm{C}$. The relative humidity of the air (\%) was inversely proportional to the temperature, with higher values in the morning, average of $61.3 \%$, than in the afternoon $(41.2 \%)$.

\section{Statistical analyses}

The data of bee visitation to flowers went through tests of normality and the data related to pollen collection underwent transformation by Box-Cox and ShapiroWilk normality test was applied for homogeneity and homoscedasticity. A Barlet test was performed at 5\% significance. Data from total visitation, visitation per period (morning and afternoon) and collection of pollen and nectar were analyzed by means of ANOVA and the means were compared by the Scott-Knott test at 5\% significance, using the statistical software SISVAR 5.6.

\section{RESULTS AND DISCUSSION}

Flowers of the five types of melon studied began to open at 5 a.m. providing pollen and nectar. Immediately the bee started visiting the flowers and the number of visits progressively increased until 10 a.m., when we recorded the peak visitation for all types of melons. From then on, the number of visits was gradually reduced until late afternoon (Figure 1), and there were no bee visits to the flowers after 4 p.m..

The pattern of foraging activity concentrated in the morning is common to several studies, but the peak hours of bee visitation to the flowers vary. Studies on Yellow melon hybrids found the time of peak visitation between 5 and 7 a.m. (SOUSA et al., 2014), 10 a.m. and 11 a.m. (KIILL et al., 2012; SIQUEIRA et al., 2012) and 11 a.m. and 12 p.m. (KIILL et al., 2011). Similar results were found for Cantaloupe hybrids 10 a.m. and 11 a.m. (KIILL et al., 2011) and Piel de Sapo 10 a.m. and 11 a.m. (KIILL

Figure 1 - Foraging pattern of Apis mellifera in flowers of five commercial melon (Cucumis melo) types throughout the day in Pacajus, Ceará, Brazil

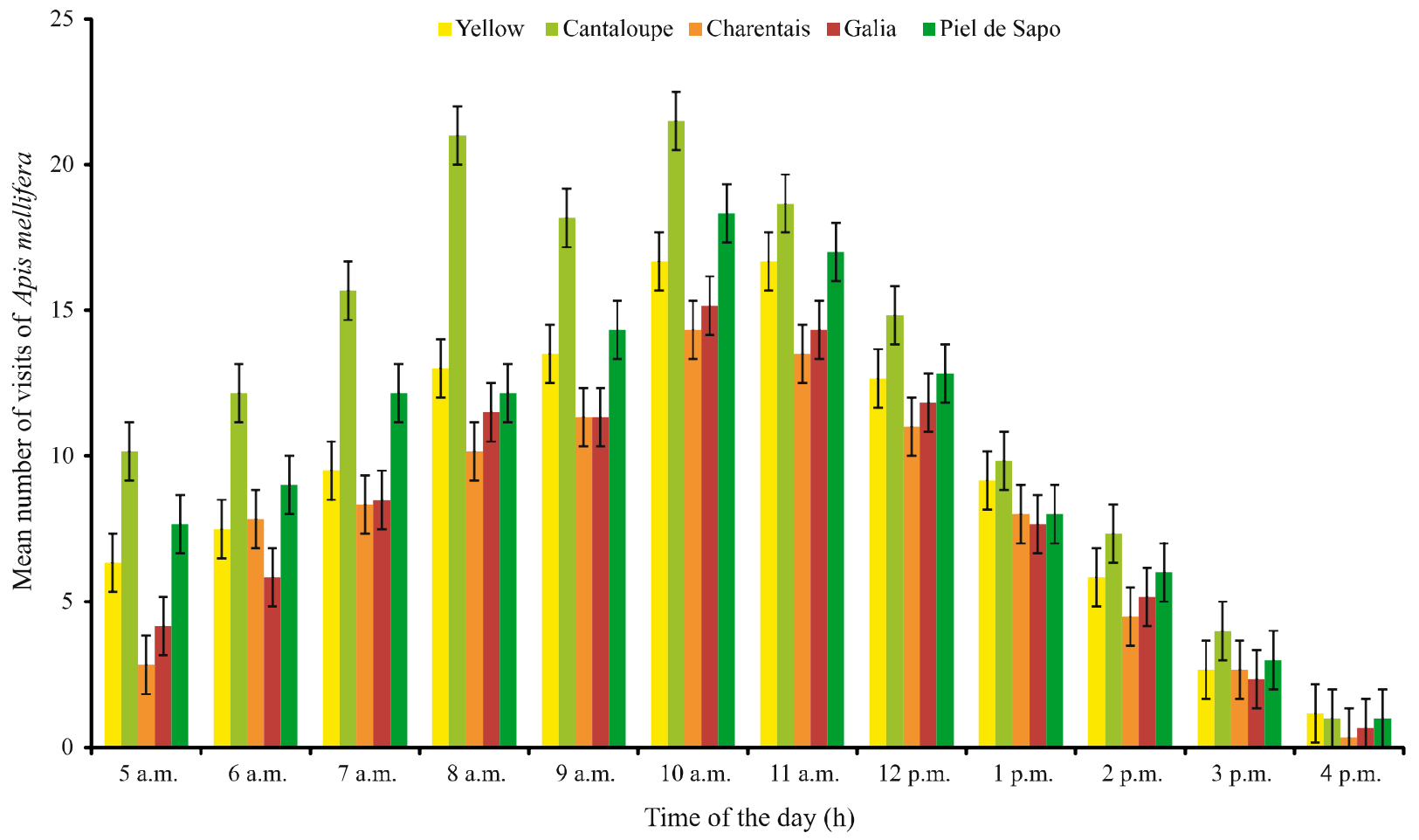


et al., 2014). These differences may be related to the time of observation, availability of other sources of pollen and nectar in the surroundings or even to the preference of the bees (DELAPLANE; MAYER, 2000). However, the peak of flower visits around 10 a.m., as observed in the present study, seems to be the most common. Therefore, concentrating foraging activity in the morning shift seems to be the general foraging pattern of $A$. mellifera for this crop, regardless of the melon type being cultivated, confirming our first hypothesis that honeybees show similar foraging pattern in the various commercial types of melon.

There was a significant difference in the mean number of visits A. mellifera did per day to flowers of the five types of melon (Table 1$)$; male flowers $(\mathrm{F}=4.933, \mathrm{p}=$ 0.0186), hermaphrodite flowers $(\mathrm{F}=10.852, \mathrm{p}=0.0012)$ and the total number of flowers $(\mathrm{F}=12.959, \mathrm{p}=0.0006)$. The flowers of the Cantaloupe melon were significantly more visited throughout the day. Next, the Yellow and Piel de Sapo types alternated at different times of the day as the second most visited type in absolute numbers, but did not differ significantly from each other. Finally, Galia and Charentais melons were the least visited types at almost all times and also did not differ from each other (Table 1).

Several factors may determine the floral preference of honey bees. In natural environments with a diversity of plant species, differences in color, size, shape, flower arrangement, quantity of flowers and resources such as pollen and nectar may be the main factors influencing the choice of certain plant species and cause some to be more visited than others (FERNANDES et al., 2019; ORBÁN; PLOWRIGHT, 2014; YAN et al., 2016). In agricultural plantations, as in the case of melon, usually only one variety or type of each plant species is cultivated and all flowers have practically identical characteristics, causing other factors, such as distance from the hive, type and amount of resource demanded and competition among floral visitors to be considered more determinant in the choice of the flowers visited (BOMFIM et al., 2016).
In melon cultivation, however, preferences for varieties or types within the species had not been considered until now because although it is common to grow different types of melon at the same period of year, areas with each melon type usually comprise a few hectares and are not close to each other. Thus, once $A$. mellifera bees are introduced into one of these areas, they do not have a choice between flowers of different melon types and although one could try to compare visitation data from areas cultivated with different types of melon (KIILL et al., 2016), the existence of many other variables inherent to each of these areas, such as size, surrounding flora, competition with wild visitors, and the differences between the bee colonies used, would not allow to draw conclusions on the existence or not of preferences by the honey bee for visiting flowers of one or another commercial type of melon.

In the present study, however, each type of melon was cultivated in eight plots randomly distributed in the same area, all within reach of the same colonies of A. mellifera. Thus, bees had options of choice under the same conditions, and were clearly able to discriminate the flowers of the different commercial types of melon, and showed preference to visit flowers of some types in relation to others regardless of their location in the mosaic of plots confirming our second hypothesis. In fact, the bees presented a graduation of preferences in which the flowers of the Cantaloupe type were preferred first, the flowers of Yellow and Piel de Sapo were secondary preference, whereas the flowers of Galia and Charentais were those that less attracted the bees.

Concerning the visitation by time of day for each type of melon, significant differences $(F=9.326, p=0.0021)$ were found only until the peak hour at 10 a.m. when the same pattern observed for the total number of visits per day was repeated, with the Cantaloupe melon being the most visited, and the Yellow and Piel de Sapo types receiving the second highest number of visits, differing to the Cantaloupe type at certain times of the day but not at others. The Galia

Table 1 - Mean number ( \pm s.e.m.) of Apis mellifera visits to flowers of five commercial melon (Cucumis melo) per day in Pacajus, Ceará, Brazil

\begin{tabular}{cccc}
\hline \multirow{2}{*}{ Melon type } & \multicolumn{3}{c}{ Number of flower visits ( \pm s.e.m.) } \\
\cline { 2 - 4 } & Male & Hermaphrodite & Total \\
\hline Yellow & $51.83 \pm 1.82 \mathrm{~b}$ & $62.83 \pm 2.94 \mathrm{~b}$ & $114.67 \pm 2.55 \mathrm{~b}$ \\
Cantaloupe & $74.17 \pm 3.94 \mathrm{a}$ & $80.17 \pm 3.44 \mathrm{a}$ & $154.33 \pm 4.81 \mathrm{a}$ \\
Charentais & $42.67 \pm 5.32 \mathrm{c}$ & $52.17 \pm 9.20 \mathrm{c}$ & $94.84 \pm 8.54 \mathrm{c}$ \\
Galia & $44.33 \pm 1.86 \mathrm{c}$ & $54.17 \pm 4.92 \mathrm{c}$ & $98.50 \pm 5.67 \mathrm{c}$ \\
Piel del Sapo & $54.67 \pm 1.58 \mathrm{~b}$ & $66.83 \pm 2.55 \mathrm{~b}$ & $121.50 \pm 2.90 \mathrm{~b}$ \\
\hline
\end{tabular}

s.e.m = standard error of the mean; means followed by the same letter in columns do not differ at $p<0,05$, by Scott-Knott test 
and Charentais types were the least visited during this period (Table 2). However, from the peak hours at 10 a.m. to the end of foraging activities at 4 p.m., there was no significant difference $(\mathrm{F}=0.294, \mathrm{p}=0.8751)$ in the number of visits to the flowers of the five types of melon (Table 2).

Knowing the time of greater bee activity in the flowers is important because it indicates when the application of cultural practices that can disturb the pollination work of the bees, such as weeding, foliar fertilization and application of pesticides, must be performed (FREITAS; PINHEIRO, 2012). Our study, therefore, produced practical results with direct implications in the use of A. mellifera for melon pollination. By demonstrating that the foraging pattern of these bees is similar in melon, regardless of the type cultivated, and concentrates in the morning with almost no activity after 4 p.m., it allows to recommend that agricultural practices with potential negative impact on bees, when necessary, are carried out after this time of the day.

Considering visits to male and hermaphrodite flowers, the visitation pattern remained the same as for the total number of flowers, in both flower genders. Cantaloupe flowers were significantly more visited than the others, while the flowers of Galia and Charentais were the least visited. However, regardless of the type of melon studied, the hermaphrodite flowers always received more visits than the male flowers (Table 1).

Visits of pollinators to flowers are essential for fruit setting in most agricultural crops. However, in plant species whose ovaries contain a large number of ovules, pollination is responsible not only for setting the fruits, but also for the size and final conformation, directly affecting their commercial value (KLATT et al., 2014). In the case of melon, for a fruit formation of the market standard, a minimum of 400 to 500 viable pollen grains must be deposited in the stigma of the flower in order to fertilize the majority of the ovules and ensure the proper development of the fruit (DELAPLANE; MAYER, 2000). Therefore, the greater the number of visits for a melon flower the more pollen grains may be deposited in the stigma, and a melon flower needs from 10 to $15 \mathrm{~A}$. mellifera visits to be effectively pollinated and to produce a fruit with the desired commercial shape and size (DELAPLANE; MAYER, 2000; MUSSEN; THORP, 2003).

It is worth noting that the use of two honey bee colonies in the experimental area, a number normally used for 0.5 ha (FREE, 1993; RIBEIRO et al., 2015), produced a bee density enough to all the hermaphrodite flowers of the five different melon types receive far more visits than the minimum number needed for effective pollination and the formation of fruits of commercial value. In fact, this density may even have produced a greater amount of visits to the flowers of the less preferred types of melon than would be observed at densities closer to those used in commercial plantations. However, it is important to note that although the number of visits that the flowers receive may be directly related to the density of bees in the area, the number of bees did not affect the preference for one or another melon type.

Table 2 - Mean number ( \pm s.e.m.) of Apis mellifera visits to flowers of five commercial melon (Cucumis melo) per time of the day in Pacajus, Ceará, Brazil

\begin{tabular}{|c|c|c|c|c|c|}
\hline \multirow{2}{*}{ Hour of the day (h) } & \multicolumn{5}{|c|}{ Number of flower visits per melon type ( \pm s.e.m.) } \\
\hline & Yellow & Cantaloupe & Charentais & Galia & Piel del Sapo \\
\hline 5 a.m. & $6.33 \pm 1.59 \mathrm{a}$ & $10.17 \pm 0.80 \mathrm{a}$ & $2.83 \pm 0.87 \mathrm{~b}$ & $4.17 \pm 1.13 b$ & $7.67 \pm 0.99 \mathrm{a}$ \\
\hline 6 a.m. & $7.50 \pm 0.56 b$ & $12.17 \pm 1.40 \mathrm{a}$ & $7.83 \pm 0.48 b$ & $5.83 \pm 0.87 \mathrm{~b}$ & $9.00 \pm 1.24 b$ \\
\hline 7 a.m. & $9.50 \pm 0.62 b$ & $15.67 \pm 1.70 \mathrm{a}$ & $8.33 \pm 1.67 b$ & $8.50 \pm 1.43 b$ & $12.17 \pm 2.13 \mathrm{a}$ \\
\hline 8 a.m. & $13.00 \pm 1.53 b$ & $21.00 \pm 2.13 \mathrm{a}$ & $10.17 \pm 1.35 b$ & $11.50 \pm 1.95 b$ & $12.17 \pm 1.10 \mathrm{~b}$ \\
\hline 9 a.m. & $13.50 \pm 1.43 b$ & $18.17 \pm 1.13 \mathrm{a}$ & $11.33 \pm 1.05 \mathrm{~b}$ & $11.33 \pm 1.72 b$ & $14.33 \pm 1.08 \mathrm{~b}$ \\
\hline 10 a.m. & $16.67 \pm 0.49 c$ & $21.50 \pm 1.09 \mathrm{a}$ & $14.33 \pm 1.36 \mathrm{c}$ & $15.17 \pm 0.47 \mathrm{c}$ & $18.33 \pm 0.95 b$ \\
\hline 11 a.m. & $16.67 \pm 1.18 \mathrm{a}$ & $18.67 \pm 2.29 \mathrm{a}$ & $13.50 \pm 1.95 \mathrm{a}$ & $14.33 \pm 2.17 \mathrm{a}$ & $17.00 \pm 1.48 \mathrm{a}$ \\
\hline 12 p.m. & $12.67 \pm 1.63 \mathrm{a}$ & $14.80 \pm 0.60 \mathrm{a}$ & $11.00 \pm 0.70 \mathrm{a}$ & $11.83 \pm 0.83 \mathrm{a}$ & $12.83 \pm 0.75 \mathrm{a}$ \\
\hline 1 p.m. & $9.17 \pm 1.40 \mathrm{a}$ & $9.80 \pm 0.98 \mathrm{a}$ & $8.00 \pm 1.13 \mathrm{a}$ & $7.67 \pm 2.26 \mathrm{a}$ & $8.00 \pm 1.16 \mathrm{a}$ \\
\hline 2 p.m. & $5.83 \pm 0.98 \mathrm{a}$ & $7.33 \pm 0.92 \mathrm{a}$ & $4.50 \pm 1.23 \mathrm{a}$ & $5.17 \pm 0.79 a$ & $6.00 \pm 1.07 \mathrm{a}$ \\
\hline 3 p.m. & $2.67 \pm 0.61 \mathrm{a}$ & $4.00 \pm 0.69 \mathrm{a}$ & $2.67 \pm 0.66 \mathrm{a}$ & $2.33 \pm 0.80 \mathrm{a}$ & $3.00 \pm 0.78 \mathrm{a}$ \\
\hline 4 p.m. & $1.17 \pm 0.47 \mathrm{a}$ & $1.00 \pm 0.45 \mathrm{a}$ & $0.33 \pm 0.21 \mathrm{a}$ & $0.67 \pm 0.22 \mathrm{a}$ & $1.00 \pm 0.52 \mathrm{a}$ \\
\hline
\end{tabular}

s.e.m $=$ standard error of the mean; means followed by the same letter in lines do not differ at $p<0,05$, by Scott-Knott test 
Regarding the floral resources exploited by the bees, they collected nectar in flowers of the five different types of melon during the entire day, but it was in the morning (before 12 p.m.) that most of the collections took place (Figure 2).

The visits to collect nectar during the morning differed significantly $(\mathrm{F}=10.108, \mathrm{p}=0.0098)$ among the types of melon, with the Cantaloupe melon being the most visited for this resource, with a mean of $35.33 \pm$ 6.62 visits, followed by the Piel de Sapo type with 29.92 \pm 6.44 visits, and the types Yellow, Galia and Charentais with $27.00 \pm 7.94,24.50 \pm 6.76$ and $23.42 \pm 6.08$ visits respectively, which did not differ from each other. In the afternoon there was no significant difference $(F=1.555, \mathrm{p}$ $=0.2598$ ) in the visits for nectar collection among the five different types of melon studied (Figure 2).

Figure 2 - Mean number ( \pm s.e.m.) of Apis mellifera visits for pollen or nectar to flowers of five commercial melon (Cucumis melo) per day shift in Pacajus, Ceará, Brazil

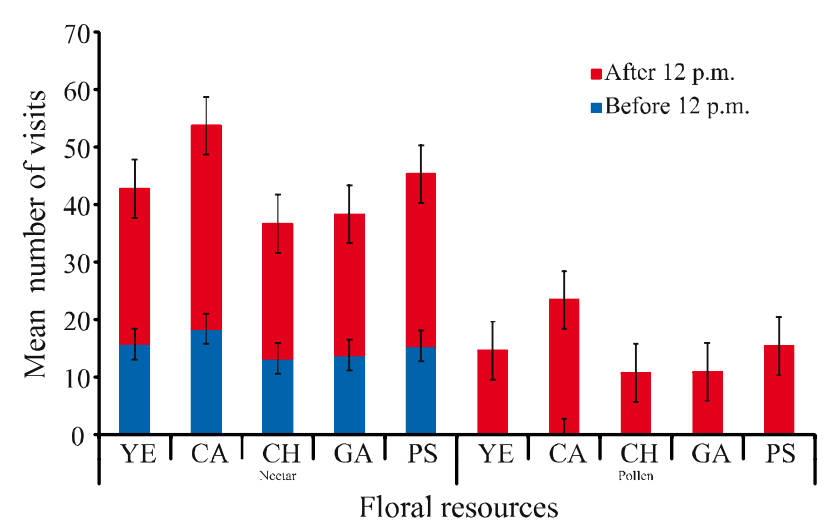

Pollen collection visits occurred only in the morning, except for one single visit to a flower of the Yellow type which occurred soon after 12 p.m. (Figure 2). There was a significant difference $(\mathrm{F}=12.543, \mathrm{p}=0.0007)$ in the number of visits for pollen collection among the types of melon. As occurred for nectar, the highest number of visits for pollen collection also occurred in the flowers of the Cantaloupe type, with a mean of $23.42 \pm 6.93$ visits, followed by the Piel de Sapo and Yellow melons with $15.42 \pm 2.87$ and $14.58 \pm 4.32$ visits respectively and the lowest number of visits occurred in the types Galia and Charentais with means of $10.92 \pm 3.00$ and $10.75 \pm 4.47$ visits respectively.

Flowers vary in the number of pollen grains they produce depending on the type of melon and gender of the flowers, but they present a maximum of approximately 25.000 pollen grains per flower, which is a low amount to flowers considered pollen sources for the honey bee (KIILL et al., 2016). Pollen is a limited resource, which is only available to bees after the dehiscence of anthers, and once removed is no longer replenished by the flower. This may explain why bees were observed collecting pollen only in the morning, probably this resource was no longer available in the afternoon. The production of nectar in melon flowers, however, occurs throughout the day (HOZ, 2007; MUSSEN; THORP, 2003) justifying the collections observed up to 16:00 p.m., and similar observations in other studies (HOZ, 2007; KIILL et al., 2012, 2016).

\section{CONCLUSION}

We conclude that honeybee foragers have the ability to discriminate between flowers of different commercial types of melon, with possible implication for the pollination of this crop. Such flower discrimination demands the use of management practices to compensate for the bees' lower propensity to visit the flowers in crops of the Galia and Charentais types. Also, the greater or lesser visitation to the flowers of the various types of melon may be associated with subtle differences in their floral traits. This should be investigated further aiming selection within the less visited types of melon for cultivars more attractive to bees. Other cultivated species with similar multivarietal cropping may also benefit from further studies in this area.

\section{ACKNOWLEDGEMENTS}

The authors gratefully acknowledge financial support from the National Institute of Science and Technology - INCT BioNat, grant \# 465637/2014-0, Brazil. Breno M. Freitas and Fernando Antonio S. de Aragão thanks $\mathrm{CNPq}$ for Research Productivity Fellowships (\#302934/2010-3 and\#312139/2017-9, respectively) and Nayanny de S. Fernandes is grateful to CAPES/Brazil for her $\mathrm{PhD}$ sponsorship. We also thank the support from the Embrapa Experimental Station in Pacajus, Brazil and Davi Silva for his help with data collection.

\section{REFERENCES}

ABOU-SHAARA, H. F. The foraging behavior of honey bees, Apis mellifera: a review. Veterinarni Medicina, v. 59, n. 1, p. 1-10, 2014.

BOMFIM, I. G. A. et al. Polinização do meloeiro. In: GUimarãeS, M. A.; ARAGÃO, F. A. S. (ed.). Produção de melão. Viçosa, MG: UFV, 2018. cap. 13, p. 220-244.

BOMFIM, I. G. A. et al. Pollination in cucurbit crops. In: PESSARAKLI, M. Handbook of Cucurbits: growth, 
cultural practices, and physiology. Boca Raton: CRC Press, 2016. cap. 11, p. 181-200.

DELAPLANE, K. S.; MAYER, D. F. Crop pollination by bees. Wallingford, UK: CABI, 2000. 352 p.

FERNANDES, N. S. et al. Volatile organic compounds role in selective pollinator visits to commercial melon types. Journal of Agricultural Science, v. 11, n. 3, p. 93-108, 2019.

FOOD AND AGRICULTURE ORGANIZATION OF THE UNITED NATIONS. Corporate statistical database - FAOSTAT. Production/Crops. Disponível em: http://www.fao.org/faostat/ en/\#data/QC. Acesso em: 27 July 2018.

FREE, J. B. Insect Pollination of Crops. 2. ed. Cardiff: Cardiff Press, 1993. 684 p.

FREITAS, B. M.; PINHEIRO, J. N. Polinizadores e pesticidas: princípios e manejo para os agroecossistemas brasileiros. Brasília, DF: Ministério do Meio Ambiente, 2012.102 p.

GÓMEZ, S. R. et al. Small sweat bees (Hymenoptera: Halictidae) as potential major pollinators of melon (Cucumis melo) in the Mediterranean. Entomological Science, v. 19, p. 55-66, 2016.

HOZ, J. C. T. Visita de abejas (Apis mellifera, Hymenoptera: Apoidea) a flores de melón Cucumis melo (Cucurbitaceae) en Panamá. Revista de Biología Tropical, v. 55, n. 2, p. 677-680, 2007.

KIILL, L. H. P. et al. Avaliação do padrão de visitação de Apis mellifera em três cultivares de meloeiro, em Petrolina-PE, Brasil. Revista Brasileira de Fruticultura, v. 33, p. 455-460, 2011. Volume especial.

KIILL, L. H. P. et al. Evaluation of floral characteristics of melon hybrids (Cucumis melo L.) in pollinator attractiveness. Revista Brasileira de Fruticultura, v. 38, n. 2, p. e-531, 2016.

KIILL, L. H. P. et al. Frequency and foraging behavior of Apis mellifera in two melon hybrids in Juazeiro, state of Bahia, Brazil. Anais da Academia Brasileira de Ciências, v. 86, n. 4, p. 20492055, 2014

KIILL, L. H. P. et al. Relationship of floral morphology and biology of yellow melon hybrids with the attractiveness of pollinators. Magistra, v. 24, p. 143-149, 2012. Número especial.

KLATT, B. K. et al. Bee pollination improves crop quality, shelf life and commercial value. Proceeding of theRoyal Society, Series B, Biological Science, v. 281, n. 1775, p. 20132440, 2014.

KLEIN, A. M. et al.Importance of pollinators in changing landscapes for world crops. Proceeding of theRoyal Society, Series B, Biological Science, v. 274, n. 1608, p. 303-13, 2007.

KOUONON, L. C. et al. Reproductive biology of the andromonoecious Cucumis melo subsp. agrestis (Cucurbitaceae). Annals of Botany, v. 104, n. 6, p. 1129-39, 2009.
MUSSEN, E. C.; THORP, R. W. Honey bee pollination of cantaloupe, cucumber and watermelon. Oakland: University of California, Division of Agriculture and Natural Resources, 2003.

ORBÁN, L. L.; PLOWRIGHT, C. M. Getting to the start line: how bumblebees and honeybees are visually guided towards their first floral contact. Insectes Sociaux, v. 61, n. 4, p. 325336, 2014.

PITRAT, M. Melon (Cucumis melo L.). In: PROHENS, J.; NUEZ, F. (ed.). Handbook of crop breeding. Vol. I: vegetables. New York: Springer, 2008. cap. 9, p. 283-315.

PITRAT, M. Melon genetic resources: phenotypic diversity and horticultural taxonomy. In: GRUMET, R.; KATZIR, N.; GARCIA-MAS, J. Genetics and Genomics of Cucurbitaceae. New-York, USA: Springer International, 2016. cap. 11, p. 2560. (Plant Genetics and Genomics: Crops and Models, book 20).

PITRAT, M.; HANELT, P.; HAMMER, K. Some comments on infraspecific classification of cultivar of melon. Acta Horticulturae, v. 510, n. 510, p. 29-36, 2000.

REYES-CARRILLO, J. L.; CANO-RÍOS, P.; NAVACAMBEROS, U. Período óptimo de polinización del melón con abejas melíferas (Apis mellifera L.). Agricultura Técnica en México, v. 35, n. 4, p. 370-377, 2009.

RIBEIRO, M. F et al. Honey bees (Apis mellifera) visiting flowers of yellow melon (Cucumis melo) using different number of hives. Ciência Rural, v. 45, n. 10, p. 8-1773, 2015.

SINGH, J.; YADAV, S.; CHHUNEJA, P. K. Foraging behaviour and role of Apis mellifera Linnaeus in pollination of Cucumis melo L. Journal of Experimental Zoology, India, v. 17, n. 1, p. 213-217, 2014.

SIQUEIRA, K. M. M. et al. Effect of agrochemicals on the pattern of visitation of honey bees (Apis mellifera) in melon (Cucumis melo) flowers in Brazilian Northeast. Julius KühnArchiv, n. 437, p. 180-183, 2012.

SOUSA, R. M. et al. Período de introdução de abelhas africanizadas (Apis mellifera L.) para polinização de melão amarelo (Cucumis melo L.). Revista Verde, v. 9, n. 4, p. 1-4, 2014.

SOUSA, R. M. et al. Requerimento de polinização do meloeiro (Cucumis melo L.) no município de Acaraú-CE-Brasil. Caatinga, v. 22, n. 1, p. 238-242, 2009.

TSCHOEKE, P. H., et al. Diversity and flower-visiting rates of bee species as potential pollinators of melon (Cucumis melo L.) in the Brazilian Cerrado. Scientia Horticulturae, v. 186, p. 207216, 2015.

YAN, J. et al. Pollinator responses to floral colour change, nectar, and scent promote reproductive fitness in Quisqualis indica (Combretaceae). Scientific Reports, v. 6, n. 24408, 2016. 